\title{
Medieval echoes. Reflection on political theories and cultural trends from European Middle Ages during American Wars of Independence and Between the States
}

\author{
Xosé M. Sánchez Sánchez \\ University of Vigo \\ e-mail: xsanchez@uvigo.es \\ ORCID iD: http://orcid.org/0000-0002-0779-3336
}

Submitted: 4 March 2020. Accepted: 2 June 2020.

\begin{abstract}
This article examines the influence of formulations and lines of European medieval thought and culture during the two main processes of American political history: the American Wars of Independence and Between the States. In these moments of enormous significance, we can perceive a series of formulations alive since Middle Age centuries; principles with a no evident but relevant influence in mentality and perception during the conflicts. These are: federalism, constitutionalism, canon law, the concept of war, the reception of the work of Dante Alighieri and his 'Divina Commedia' and the reception of chivalric medieval culture and the Arthurian tradition.
\end{abstract}

KEYWORDS: European Medieval History; Contemporary American Politics; Medieval Political History; Medieval Cultural History; Comparative History; Diachronic; Cultural Studies.

Citation / Cómo citar este artículo: Sánchez Sánchez, Xosé M. (2021) "Medieval echoes. Reflection on political theories and cultural trends from European Middle Ages during American Wars of Independence and Between the States". Culture \& History Digital Journal, 10 (1): e011. https://doi.org/10.3989/chdj.2021.011

RESUMEN: Ecos de la Edad Media. Reflexión acerca de las teorías políticas y líneas culturales de la Europa medieval durante las guerras americanas de Independencia y Secesión.- Este artículo examina la influencia de formulaciones y líneas de la Europa medieval a través del pensamiento y la cultura durante los dos principales procesos de la historia política Norteamericana: la Guerra de Independencia y la Guerra de Secesión. En esos momentos de enorme significación podemos percibir una serie de formulaciones vivas desde los siglos medievales; principios con una no evidente pero sí relevante influencia en la mentalidad y percepción durante los conflictos. Estos son: federalismo, constitucionalismo, derecho canónico, el concepto de guerra, la recepción del trabajo de Dante Alighieri y su 'Divina Commedia'; y la recepción de la tradición cultural de la caballería medieval y artúrica.

PALABRAS CLAVE: Historia medieval europea; Política contemporánea norteamericana; Historia política medieval; Historia cultural medieval; Historia comparativa; Diacronía; Estudios culturales.

Copyright: $(92021$ CSIC. This is an open-access article distributed under the terms of the Creative Commons Attribution 4.0 International (CC BY 4.0) License. 
He recognized on the sign, however, the ruby face of King George, under which he had smoked so many a peaceful pipe, but even this was singularly metamorphosed. The red coat was changed for one of blue and buff, a sword was stuck in the hand instead of a sceptre, the head was decorated with a cocked hat, and underneath was painted in large characters, 'General Washington'.

\section{Washington Irving, Rip Van Winkle.}

The observation of the complex historical processes requires the consideration of the multiple layers that compose them; some of those sheets are evident, others are hidden under facts and conjunctures. This paper is not about analogies, circumstantial parallels or inadvertent medieval echoes voiced by eighteenth or nineteenth American political leaders. My perspective focus in the medieval theoretical and cultural principles that, obscured by mere changes in rhetoric, arrived and exerted their influence on political trends in North America. The choice of both limits and periods, so distant in time and space, is neither random nor based on a mere playful comparison. This article considers both moments in the shaping and examination of the long historical duration, especially sensitive in thought and in cultural forms.

Cultural trends and political thought of European Late Middle Ages not die with the change of period in fifteenth century. The influence of some conceptions is hidden but present even nowadays, especially in the historical events - as processes, not facts- with most complex definition. Some of these have survived as sotto voce whispers behind the transformations, as those strange signals perceived by Rip Van Winkle once he woke up from his long slumber.

\section{A BRIEF THEORETICAL APPROACH}

Medievalism is expanding its frontiers again. The multiple lines of work since nineteenth century on what D. Mathews calls asynchronous medievalism-going further than a chronological conception of Middle Ages-, have led even to questioning the concept of medievalism itself, with the possibility of taking form not as a single discipline but a set of themes (Matthews, 2015, pp. 5455 and 119-120). Nowadays, and crossed the twentieth century and the irruption of interdisciplinary studies (see: Aurell, 2005-2009-2015), the expansion comes partially from the exploration of diachronic.

The definition of common principles for Middle Ages and its presence in different geographical spaces grew in recent times on historiography with the called Global Middle Ages (Holmes and Standen, 2015; Holmes and Standen, 2018; Frankopan 2019), "seeking to view world cultures in synchronic and longue durèe perspectives rather than isolated nationalistic terms" (Amer and Ramey, 2018, p. 175). The attention to diachronic and comparative studies in Middle Ages is also one of the strongpoints in the most recent international researches and the orientation is extended to multiple fields of medieval studies to reveal the "signs of diachronic growth" (Berman, 2019, p. 377) trying to overcome the synchronic practically but also from a theory environment (Simpson, J. 2007, pp. 17-19). This is based on a long stream of studies, with diverse fortune, which begins with the Annales School and arrives nowadays to fruitful fields as the Comparative Medieval History. The results are both fields and study objects expanded, origin of such suggestive editions as the review Postmedieval, published since 2010 until today and focused on trans-cultural and trans-chronological perspectives.

In twentieth first century is especially significant the approach to cultural studies, not only in the synchronic perspective of medieval research but also in the diachronic vision of the long terms and avoiding a Eurocentric vision ${ }^{1}$. Historiography is following the definition from the conceptualization and work of the Annales generation in the middle of twentieth century, mixing with the Anthropology and Cultural Anthropology in the sixties, and extending the gaze beyond Medieval times into the persistence in modern and contemporary ages. One of the most prolific results for society is the strong line of re-enactment as a socio-cultural construction (Sautkin, 2015, p. 29) that materializes from both medievalism and American wars in the "modern reinterpretation of the past" (Meriwether and D'Amore, 2012, p. xiii). In the case of medieval History is especially developed in the called neomedievalism(s) (Lukes, 2014, pp. 1-2) but also as a didactic recourse linked to "living history" (Español, 2019, p. 336).

Our study follows also those global perspectives ${ }^{2}$ and attends to diachronic and relationship of thought structures helping to understand how some of the main reflections and political formulations of the thirteenth to fifteenth centuries, maintains and spreads its influence through centuries, adapting on new circumstances of a new age and a different continent. The starting points are the main medieval conceptions on society and political structures and the arrival will be the presence and influence of these in the political conceptions of the two main processes of American political history: the American Wars of Independence and Between the States.

In the long evolution of European Late Middle Ages, inside political conceptions and common behaviours through culture, we can take the first third of fourteenth century as the beginning of the change from Medieval to Modern Ages (Tavares, 2008, p. 225; Black, 2009, p. 36). The conflict between Papacy, with John XXII (13161334), and Empire, headed by Ludwig IV von Oberbayern of Wittelsbach (1314-1347), is of course the clash of two powers but also the confrontation of two conceptions of State and society (Seibert, 2014). The auctoritas [authority] of the Pontificate had been formulated and defended mainly since Innocent III, in the beginnings of thirteenth century, but now, one century after, the strength of Civil State was capable enough to defend its independence. Around the Empire proliferate and grows, in first half of the fourteenth century, political formulations and authors that emphasize the main and initial lines to guide Modern 
States, with Marsilius of Padua (see: Godthardt, 2014), William of Ockham and John of Jandun as main figures of the secular political thought. But this is not an autogenous evolution. They receive the medieval tradition and they rethink some feudal and traditional conceptions changing the basis of concepts (Black, 1992; López Alcaide, Puig Montada and Roche Arnas, 2018). The final goal is the theoretical construction of Modern States (not National, not yet) upon a stronger central power. France, Spain, England and Portugal are the main kingdoms/states affected and involved on this process, with a clear "relationship between governance and wealth at intersections of culturepolitical and socio-economic history" (Yarrow, 2018, p. 215$)^{3}$.

This is the well-known evolution where this paper begins. These lines of thinking are political, in a process of re-consideration of Middle Ages that affected to the edification of new European nations in nineteenth century (see: Evans and Marchal, 2011), but also fixed in cultural forms as Literature. From here we trace their presence in Modern times (McMullan and Matthews, 2007) and they do not remain motionless in Europe but travel through the ocean. The transfer and implementation of social and political structures to the New World, implies also the arrival of these political conceptions and cultural trends (Herlihy 1968; Nelson-Campbell and Cholakian, 2017)4, not as historical justifiers for actions ${ }^{5}$ but as conscious and unconscious characterizers. The particular evolution of spaces and colonies derived in different evolutions not only of thought but of political thought derived or with the presence of elements with medieval origins. The identification will be easier as bigger and heavier the case we examine.

Following this path, we can determinate the medieval conceptions that survived, in American case, until eighteenth and nineteenth centuries and affected to the Wars.

\section{POLITICAL MEDIEVAL THEORIES AND THE WAR OF INDEPENDENCE}

Recent historiography has reflected on the ways to improve the analysis of Constitutional History through the consideration of comparative principles through diachronic (Collings, 2017; Møller, 2015). The focusing on medieval Constitutional lines and its comparison on modern or contemporary follows an intermittent tradition of studies along twentieth century. Very close to that point, we follow here not a comparison but the reception and reformulation of medieval principles.

Eighteenth-century American intellectuals have relished classical and medieval history, especially those aspects of ancient history presumed to offer precedents and templates for their young democracy. In the words of Shamir Brice, "[the] founders would have had to rely on the lessons recorded from antiquity since there was no precedent in eighteenth-century Europe or Asia for true republican government" (Brice, 2015, pp. 17). As the factual and political process, the conceptualization was also complicated; possible models as Italian republics were insufficient, being economic-administrative states and oligarchies but not national political entities yet. This attention is not perceivable only in America, but also in the first political formulations of the close Canada with the attempts of the theorist James Martin Cadwell (1784-1842) to institutionalize some medieval political models in the new construction (Ryan, 2017, p. 173).

Political conceptions inherited or influenced in some way by the European medieval tradition helped to frame the War of Independence. During the second half of eighteenth century, three concepts and theoretical spaces show the main penetration of pre-modern thought: federalism, constitutionalism, and canon law. Each emerges from legacy components of earlier political discourse.

The initial formulation of federalism reveals its European spring points, especially those rooted in Ancient Greece, Rome and their medieval successors. ${ }^{6}$ The proper medieval federal ideals developed from the political theoretical system that spread in Greek and Roman civilizations as «classical republicanism». A set of principles that, mutatis mutandis, survives the imperial hecatomb and is received in the Europe of the Germanic kingdoms. ${ }^{7}$ During the American Revolution, they served to combine the self-rule principle with shared rule and gave birth to the federal union of the colonies. ${ }^{8}$ The inherent stresses of this unlikely merger are implicit in the standard historiography of the ensuring War Between the States. The Revolutionary War and the subsequent definition of independence would problematize the civil republicanism as "linking the practice of virtue with the presence of freedom and the common good of society" (Boisi Center..., 2007, p. 6).

Ideals of a republican political framework derived from Greek city-states passed along in a highly modulated state to European Middle Ages. Following this path, the principle of the commonwealth mixed with the incorporation of the three estates, the called ordos [order] into the management of power, is already present on the late medieval England or in the Castilian kingdom, in the beginning of the fifteenth century, where we have the outstanding presence of the concept egualdat [equality] (Ruiz, 2013, p. 277). On the Iberian Peninsula, republican formulations also arose in the universities and in some sectors of the intelligentsia. These comes to a halt under the Catholic Monarchs toward the end of the fifteenth century but never completely forgotten, especially in the persistent model of models of governance systematised among Italian republics as some of the most visible emergent states of the new order. More related with the American Revolution, the concept of sovereignty arises in the public political British life, with its first presence in the Act in Restraint of Appeals of 1533 (LaCroix, 2008, p. 10). ${ }^{9}$

The arrival of this set of ideas and formulations to America takes the form of a new way of interpretation in the middle of the theological and political thoughts through the Lutheran Reform. The development of the discourse about the individual freedom gave new and different paths to the inherited medieval theology, now politicised on its way to the continent ${ }^{10}$. Lutheran reform 
reinforces the power of the individual as the basis to build a new kind of relationships. This gave birth to a new conception on right marked especially by individualism, both moral and political, that held the autonomous secular and civil develop; an individualism that changed in the Revolution with the cession of some attributions to the government.

Not so much after that the German philosopher and theologian Joannes Althusius offered towards 1610 a modern definition of federalism, receiving the tradition of the medieval corporate bodies and projecting it to the new times modelling the federalist structure as the formulation of a collective contract (Montani, 2014-2015, p. 5). This is a conception maintained through contemporary times in the new cultural and political waves.

These are some of the bases for the contractualism of Modern age but especially for the federalism exhibited on American Revolutionary times while took place the intense post-Independence debate about which one, Federation or Confederacy, would be the ideal political system for the new nation. This question emerged especially after the approval of the Articles of Confederation by the Second Continental Congress in 1776. The collection known as The Federalist papers developed all this matters in order to the ordination and organization of the new Union. Published by James Madison, John Jay and Alexander Hamilton between October 1787 and August 1788 these 85 articles were edited and compiled as a volume in 1788, The Federalist: A Collection of Essays, Written in Favour of the New Constitution, with the sense of reflect and explain the possibilities of the news ways for the United States and its Constitution. Most of those principles lay on these letters, as the personal individuality or the foundation of new realities arising from them:

\footnotetext{
Nothing is more certain than the indispensable necessity of government; and it is equally undeniable, that whenever and however it is instituted, the people must cede to it some of their natural rights, in order to vest it with requisite powers. It is well worthy of consideration, therefore, whether it would conduce more to the interest of the people of America, that they should, to all general purposes, be one nation, under one federal government, than that they should divide themselves into separate confederacies, and give to the head of each, the same kind of powers which they are advised to place in one national government (Carey and McClellan, 2001, p. 5).
}

James Madison takes as example of confederacies the social and pre-feudal space of the Carolingians. The feudalism is always associated here with the Confederation as political system with so clear adjectives by Alexander Hamilton: "the times of feudal anarchy" or "the separate governments in a confederacy may aptly be compared with the feudal baronies", on paper n. 17. The reference to the medieval political scaffolding is not free or casual, but so well and deep though. This is confronted to the Germanic configuration with the diet, the organic legisla- tive institution for Holy Roman Empire created on 1356 by Emperor Charles IV, as expression of the power. The Empire (Carey and McClellan, 2001, p. 90) with that diet is a remarked referent along the whole paper $n .19$.

Here we have also presented that consideration of equality, not only for individual people but also now for territories and as strongpoint for the Union:

The most sanguine advocates for three or four confederacies, cannot reasonably suppose that they would long remain exactly on an equal footing in point of strength, even if it was possible to form them so at first: but admitting that to be practicable, yet what human contrivance can secure the continuance of such equality? Independent of those local circumstances which tend to beget and increase power in one part, and to impede its progress in another, we must advert to the effects of that superior policy and good management which would probably distinguish the government of one above the rest, and by which their relative equality in strength and consideration, would be destroyed (Carey and McClellan, 2001, p. 18).

These letters are opposite to the called 'anti-Federalist papers', wrote also after the Constitutional Convention among others by Patrick Henry or NY Gov. George Clinton. Curiously, here we can read some of the same or very similar values (not the way to implement them) than in the Federalists:

Those furious zealots who are for cramming it down the throats of the people, without allowing them either time or opportunity to scan or weigh it in the balance of their understandings, bear the same marks in their features as those who have been long wishing to erect an aristocracy in this Commonwealth (Borden, 1965, paper $\mathrm{n}^{\circ}$ 1). [...] In a national government, unless cautiously and fortunately administered, the disputes will be the deep-rooted differences of interest, where part of the empire must be injured by the operation of general law; and then should the sword of government be once drawn (which Heaven avert) I fear it will not be sheathed, until we have waded through that series of desolation, which France, Spain, and the other great kingdoms of the world have suffered, in order to bring so many separate States into uniformity, of government and law; in which event the legislative power can only be entrusted to one man (as it is with them) who can have no local attachments, partial interests, or private views to gratify (Borden, 1965, paper $n^{\circ} 3$ ). [...]

A constitution [the one voted on Convention] which, in my humble opinion, contains the seeds and scions of slavery and despotism (Borden, 1965, paper $\mathrm{n}^{\circ} 16$ ).

From here: Constitution and republic. The line known by historiography as "constitutionalism", for European Middle Ages-mainly France and England-, has been delimitated and re-defined many times, with the general conception of the theoretical formulation of an authority with powers limited by some kind of principles of justice and law (Kaeuper, 2013, p. 101). The materialization is diverse from Anglo-Saxon England and is uneven the 
coincidence with that exactly characterization (Kaeuper, 2013 , p. 15). But there are indubitably some examples that can show how the established European feudal power, mainly from royal initiative, not only allowed but assumed the representative forms and political government with the participation of the community; of common legal institutions and political spaces developed in some cities and regions, especially on spaces that had some kind of independence for political or economic management. These are the cases of the treaty of the main Flemish cities with English kingdom in 1213, Louis VIII of France with Languedoc in 1226 or Alphonse IX of Leon with the transfer of the county of Toulouse in 1249 (Blockmans, 2008, pp. 17-18). We must not mistake and overestimate this: the pre-constitutional spaces in Middle Ages born from and inside the feudal system, especially as a merely feudal way to avoid some kind of aggression from other power, both laic with the king/nobility or ecclesiastical with the Church. This is the case of the English Magna Carta in 1215 - and its developing as historiographical myth (Helmholz, 2016, pp. 1476-1478) - or the progressive increase of participation of cities and ordos in the Castilian-Lionesses representative institutions. But it is also true that these are also remarkable points of reference for the future evolution of the constitutionalism developed in that space; especially the first decreta of the $\mathrm{cu}$ ria gathered in León in 1188 (see: González Díez, 2018) and the Magna Charta that reinforced the constitutionalist conceptions of the contract and pact between govern and governed and the idea of a 'fundamental law' (Satrústegui Gil-Delgado, 2009, p. 253).

This widespreaded the European late medieval and high modern legal configuration through the called ius publicum Europeum that expanded to the new American Colonies with the colonization by the European powers. With a similar society developed both in Europe and America "it is in this institutional framework-the $\mathrm{Na}$ tion-State - and in this geopolitical landscape - the Atlantic world - that the doctrine of constitutionalism was elaborated" (Buratti, 2016, pp. IX-X).

Taking this context as a highlighted space there are two contexts that prefigures the modern constitutional principles applied in the new political programs and formulations of the American eighteenth century emanated from Revolutionary war: the constitutionalism in medieval England; and the Conciliarism in the fifteenth century.

The medieval British constitutionalism is a far away point of beginning for the American constitutional history, in a very well-known relationship that I will not repeat (Freedman and Spiegel, 1998, p. 683). The idea of opposition between powers in British history as an antecedent of American Revolution is not a supposition but present in the political American thought. Alexander Hamilton, in The Federalist paper n. 26, remarks the evolution from Norman Conquest in 1066: "In England, for a long time after the Norman conquest, the authority of the monarch was almost unlimited. Inroads were gradually made upon the prerogative, in favor of liberty, first by the barons, and afterwards by the people, till the greatest part of its most formidable pretensions became extinct" (Carey and McClellan, 2001, p. 128). This leads to the British revolution of 1688, when "English liberty was completely triumphant" (Carey and McClellan, 2001, p. 128). The arriving of the winds of independence to America on eighteenth century is here conceived as a recent station on the railway of the historical Anglo-Saxon political space, and mixed with a concept of war more related with medieval times than the modern war. This conception is patent not only in the time of Revolution itself, but also in one century later. In words of the US senator from New Hampshire John Parker Hale, on the speech that gave in the Senate on December 5, 1860:

away back, centuries upon centuries in English history, where power and principle contended against each other with alternate success and defeat, - in all those centuries there had been going on the contest which is culminating in our experiment here; and no patriot blood that was poured out on the battlefields in the civil wars of England has been insignificant in relation to this conflict (Cheney, 1910, p. 20).

The practice of the constitutionalism became really effective and stronger after the Reform, in sixteenth century, but the theoretical principles are not from Modern ages but from the opposition between Church and Empire in eleventh and twelfth centuries, inside the Investiture Controversy. The limitation of authority and the definition of spheres of power grew as a strong theoretical point of this matter, even though we have to wait 150 years for the new proceedings in the conflict between the pope John XXII and the emperor Louis of Bavaria and several centuries for the practical application of these principles (Esbeck, 2004, p. 1401).

The conception of the state as a corporation, conceived as strong point for the "limitation of the governmental power by the law" (Enlow, 2001, p. 2), evolved from these capital theoretical points to understand the medieval echoes on Revolutionary times. The forms of government for late medieval monarchies in Western Europe involved the communication with councils and a sort of initial representative systems and evolved, entering sixteenth century, in new conceptions of "popular" and "the people" (Grewal and Purdy, 2018, p. 664). The medieval concept of natione-when it is considered and not before Late Middle Ages-departs on the "nation" as a community conforming one body with the king as visible head. Referring on English Modern formulation the difference is clear: "by maintaining the separation between the king's capacity as head of the corporation of the kingdom and his private capacity, England avoided the personal absolutism of France" (Enlow, 2001, p. 6).

On Independence War and early US history times, the concept as corporation was clear; so much clear that the Court gave some crystal clues in 1779, on the case Republica vs. Cornelius Sweers, as Eric Enlow refers: "from the moment of their association, the United States necessarily became a body corporate". The Constitutional Conven- 
tion remarked this conception in 1787 with a close link between the corporate conception of the state and the legal limitation of government. Enlow collects and analyse enough examples with many definitions and clear references in the line that leads us to European medieval constitutionalism and civil republicanism as theoretical origin of the process (Enlow, 2001, p. 10-11).

This republicanism received and developed on American Revolutionary times remarked also the importance of the religious space, separated from the State but also important as origin of required values for the new government in order to avoid corruption in one system that were going not to depend on force or fear but on freedom. Distinguished figures as George Washington and John Adams pointed on that (Boisi Center..., 2007, pp. 6-7). Literally, from the farewell George Washington address, on 1796:

Of all the dispositions and habits which lead to political prosperity, religion and morality are indispensable supports. In vain would that man claim the tribute of patriotism, who should labor to subvert these great pillars of human happiness, these firmest props of the duties of men and citizens (Washington, 19 September 1796).

Church and religion also, because this process takes another strongpoint that goes back to Middle Ages: the canon law that guided the government of the Roman Medieval European Catholic Church. This theoretical space mainly develops between tenth and twelfth centuries, marked by the ideal expressed by the canonists that represents Church as a body, a theological Holy Body of Christ that comprises all and every Christian. When the cities emerged as the growing power of Europe, the civilian theorists and thinkers borrowed those conceptions in order to refer the early attempts of State, with these ideas perfectly integrated on British public law of the fourteenth century (Enlow, 2001, p. 18). At the same time canon law adapted the principle of quod omnes tangit ab omnibus approbari debet, from the Roman law through Justinian Codex Iuris Civilis, with the sense of a first majority rule (Condorelli, 2014, pp. 60-63)

In this sense Conciliarism has a lot to say about that on early fifteenth century, developed from the heart of the Great Schism (1378-1417) (Landi, 1985; Girgensohn, 2007). The solutions to the division of the Christian Roman Church came not from one pope (nor even three at same time in 1410), but from the Council. This institution was conceived as the expression of the body of the Church and of the whole Church herself, in one attempt of breaking the huge power of the one-person-government and move the institution to the government of the Council as legal body, especially in the Council of Basileia at 14311445. This is the idea of the people, the addition of singularities, as superior to the personal power. This kind of Councillor's representation materialised one ruling model that was transferred easily and soon to the secular space, with a more or less advanced configuration depending on the countries/kingdoms/nations but with a remarkable influence to the future (Blockmans, 2008, pp. 13). Now the theoretical idea is the develop of an ecclesiastical constitutionalism, with a Conciliar theory as a "ecclesiological doctrine" (Oakley, 2003, p. 223).

But with the development of their reflections, the canonists' formulations grew from Church to political State even from fourteenth century. New ways that spread on Europe and, after that, arrived through the European emigrants to America with no state but ready to form a civil political body (Enlow, 2001, p. 23). This tradition is the ancestor of We the people... and the consideration by the colonies and settlers that they could establish a corporate body and a self-stablished identity, when they declare in the Declaration of Independence that these United Colonies are, and of Right ought to be Free and Independent States.

Even though most of the formulations on American Revolutionary process are new, fresh and developed from the Enlightenment, some of these theoretical spaces sink their roots on Medieval European conceptions, as civil republicanism, canon laws or Conciliarism.

\section{PERSISTENCE OF POLITICAL THEORIES AND MEDIEVAL CULTURAL TRENDS ON BETWEEN THE STATES CONFLICT}

Consideration on cultural inherited or influenced elements is not only de definition of the construction of knowledge but the definition of the social-cultural pattern that characterize society (Belkot, Kandulski and Kosinska, 2014, p. 36-37). The outbreak of the American Between the States War, the worst conflict on internal US history, grew also along all the nineteenth century accompanied by the reception, assumption and adaptation of some concepts inherited from European Middle Ages and received halfway between the cultural content and the political reflection. These are mainly: the proper concept of war; the reception of the work of Dante Alighieri and his Divina Commedia; and the reception of chivalric medieval culture and the Arthurian tradition. The Romanticism mixed this medieval cultural tradition with the new nationalist waves in a way that influenced the conception of Union, the social space of the country/nation in the conflict North-South and some of its values on antebellum, during war and post-bellum periods.

The most general concept with a medieval past on American Between the States war is the mental underlying concept of the war itself and the moral religious sense of the proper war: the saving of the country, either North or South, with the help and mediation of God. The sense of Holy War is obviously out of this consideration, but the mental space for the association between war and religion link us with the European Middle Ages political and practical theories about war and conflict. The use of the language of martyrdom and personal sacrifice that implies the war, with the presence in the press of texts, papers and formulations related with the religious orientation of war, gives us the point of this question. Something that was especially present with the break of the unity in the Confederation about its civil religion concepts when the defeats began to come (Stout, 2006, pp. 17-19). 
God and the divinity, the claim for help in war, inherited from Ancient times, developed one of the main lines in medieval warfare, especially with the Crusades and the European military orders. ${ }^{11}$ The strength of medieval Church from a social, economic and mental point of view, mixed with the political sense of presence in the geopolitical European map, explains the development of one political-religious theory since middle of eleventh century that formulates the war as a matter of divine purpose or intervention; Bernard of Clairvaux in twelfth century is the main exponent.

When we get to the antebellum and American Civil war times, these considerations diffused and diluted through two processes that had been developing from a long time ago: the configuration of Protestantism, Calvinism and other religious lines in the Christianity since sixteenth century; and the Enlightenment and develop of the Age of the reason in the eighteenth. The divine influence on war conceptions have not disappeared but remained on a minor extension and with a more diffuse influence on the collective mentality. ${ }^{12}$ Maurice Dowling gives us one balanced point:

\begin{abstract}
Although it was not a 'war of religion' in the traditional sense, it can nevertheless be described as a 'religious war'. [...] It was not a war between different religions in the manner of the medieval 'Crusades' or the French wars of religion, nor was it a war to determine the nature of the established Church and its constitutional position [...]. Nevertheless, religion (which for the majority of church attenders in nineteenth century America meant evangelical Protestantism) provided justification for the war; it shaped people's reactions to military successes and failures; it became the foundation for understanding the war both during its course and afterwards (Dowling, 2009, p. 39).
\end{abstract}

One of the best testimonies we can read about the materialization of this influence came after the war, on the second inaugural address of the president Lincoln, on March 4 of 1865: "[the two contenders] both read the same Bible and pray to the same God, and each invokes His aid against the other".

The influence in the US along the nineteenth century of the mixture of the Romantic interest in medieval times with nationalism had a strongpoint in the reception of the Dante Alighieri's Divina Commedia (1304-1321), with the medieval conceptions that transmits, and its interpretation on both North and South. This is a process that takes place also in other nations through same time, as in Germany beginning in the middle of eighteenth century and giving birth to a whole tradition of interpretation and exegesis that extends until twentieth century (Lampart, 2010, pp. 277-278), upon a strong relation with Romanticism (Kuon, 1996, p. 304).

As Joshua Steven Matthews remarked, the development of republican nationalism and the sense of federalism pulled for the diffusion of this Italian work especially in the antebellum period: although was barely unknown in the beginning of the century, was one of the most read in the second half. In this political develop the matter of Italian unification gave North America an example of needed cohesion:

The coinciding political struggles in the U.S. and Italy, from the 1820 s to the 1860 s, made contemporary Italy a relevant socio-political lesson for the United States, as the northern states struggled to maintain the unity Italy had just achieved. About this lesson Dante had much to say, and so he became a kind of mediator between his American admirers and their understanding of the relationship between Italian nationalism and the U.S. politics of sectionalism (Matthews, 2012, pp. 26-27). ${ }^{13}$

The Italian mirror became clear in the antebellum period. We have examples as the already mentioned speech of the US senator John Parker in 1860:

\begin{abstract}
When the classic states of Italy, taught by the bitter experience of centuries, are seeking, by a consolidated constitutional government, to come together and unite their energies for liberty, for independence, and for progress, if we, untaught by all the past, reckless of the present, and blind to the future, should madly dash ourselves upon this dark ocean, whose shores no eye of prophecy, or of faith can discern, we shall present a sad spectacle to the world (Vance, 1910, p. 27)
\end{abstract}

When the war came, the Divina Commedia was a strongpoint on the theory spaces for the unification. This materialised in the Henry Wadsworth Longfellow translation of the book that he began during the war, in 1862, finished in 1863 and full published in 1867 (Matthews, 2013 , p. 315). Longfellow was not alone on his work and even he was not the first nor the only one. The American cultural interest in Dante in the 1860s is not something fortuitous, spontaneous or abrupt; the explanation is in "antebellum discourses on the nature of federalism, the identity of the American nation, and the proper restrictions and extensions of states' rights" (Matthews, 2013, p. 316).

Readers of the Union considered Dante and his work as a support for a unified and secular state, a support for the need of a strong and united State, a critic for traitors and rebels and Dante's travel as the travel of a divided and re-united Nation. ${ }^{14}$ Readers of the Confederation gave the Commedia and Dante's political theories the sense of support for a Confederate nation-state transcending the conflict and focusing on the "national" patriotism with the Confederate States of America constituted in 1862.

The medieval thinking gave the nineteenth century nations one different perspective; not the medieval properly feudal way of thinking, but the new ways of the late Middle Ages on its way to the Renaissance. The new formulations for the Modern states grew in the Trecento along the opposition between Papacy and Empire with John XXII and Louis I of Bavaria. This is the time of Miguel de Cesena and William of Ockham with the new formulations of the laic and not-yet-but-soon power of the States; the formulation that raised the federalism and 
the new consideration of nation was born. This applies later on nineteenth century through Dante to the young American nation and the efforts for re-unification during War Between the States. The results of the reception of Dante's reflections and work in American antebellum war and Between the States War times are similar than the line that we can define on the works in Late Middle Ages: the way (slower on medieval times) from territory to nation; from kingdoms/states to Union.

Next to this interpretation, we can follow another suggestive path: the image received through Dante of the Holy Roman Empire, the unification of Italy (Matthews, 2013, p. 330) and its application to the American efforts for re-unification, especially in the Union. The mixture between the theological space of a Christian patriotism and the political vision of the unification -Italian but also North American - supported the political ideal of the unity and the point to reconstruction. Even further, the matters and events occurred during Dante's age allows to Between the States War contemporaries to better interpret the facts they were living. In thirteenth and fourteenth centuries, the Guelph and Ghibelline opposed two different visions of its time: welfen following the house of Bavaria and their later support to the Church and the papacy; and Ghibelline around Waiblingen castle and Hohenstaufen house, supporting Holy Roman Empire and the emperor. On fourteenth century, this is not the opposition between Bavaria and Hohenstaufen but the confrontation between two conceptions of facing the future: the Guelph with the defence of the Papacy and Church, and the Ghibelline with a laic and civil strong power. This opposition came especially evident in spaces as Florence and some Italian republics of the Trecento. The development of the American Civil War, mixed with the diffusion of the Dante's work and his conceptions on antebellum period, spread the conception of the North and South as the opposition of Guelph and Ghibelline, with two sides of the same political space faced by two different evolution models. This is not an interpretation but a fact: the essay of Herman Melville Battle-Pieces and Aspects of the War (1866) gives us the measure of this conception, turning it around in order to overcome the conflict and go beyond the differences:

Were the Unionists and the Secessionists but as Guelphs and Ghibellines? If not, then far be it from a great nation now to act in the spirit that animated a triumphant town-faction in the Middle Ages. But crowding thoughts must at last be checked; and, in times like the present, one who desires to be impartially just in the expression of his views, moves as among sword-points presented on every side (Matthews, 2012, p. 68).

As Joshua Matthews points this is a warning from Mellvine, because of the irresolution of the medieval conflict: "Melville's response attempts to transcend the notion that either Guelph or Ghibelline are ideologically superior, arguing instead that this historical example is an important warning because the Guelph-Ghibelline feud was never satisfactorily resolved" (Matthews, 2012, p. 68).
Related with the Dante's reception the influence on medieval literature and mentality is also patent on US ante and post bellum literature. The influence of the Romanticism, and a literary and artistic wave mixed with the political expression of the national revolution's movement, explains better this presence. In Between the States war times some editions fixed the mentality of medieval chivalry and armed nobility, especially the short story Poor Richard, written by Henry James and published on 1867, that narrates the love story between Richard Maule and Miss Gertrude Whitaker during Civil War. As background underlies some of the medieval knight values, attributed now to the figures of the main characters, Richard and Severn, which share the view of Richard as a traditional medieval knight and a set of values that "recall the temptations that knights in medieval Arthurian legend, such as Gawain in Sir Gawain and the Green Knight, endure to prove their adherence to the chivalric code" (Zenari, 2015, p. 19).

The diffusion, reading and expansion not only of medieval literature but of Arthurian literature has its main general chronological space in nineteenth century, related with the Romantic Movement and exacerbated with search for roots and ancient past in the young Nations. As occurred with the political medieval substratum also in Canada, and again through James Cadwell, the English chivalric society inspired new looks and reading on medieval sources, more linked here with the cultural than social (Ryan, 2017, pp. 185-186). In Between the States America the chivalric sense and values, with the diffusion of the Arthurian world, has its influence in the material fact of war and the combat itself. Here the meanings of the personal develop of the fighting and the practical confrontation of armies is closer to the medieval conceptions on war on both sides. The terms of cowardly or bravery continue the pattern described for medieval and renaissance armies, marking certain difference "from the normative expectations that characterize 'attention to duty' in most Western armies in this century" (Marlowe, 2011, p. 18). ${ }^{15}$ This is the last time these concepts were applied in US army; in global wars, this maintained more time, until twentieth century conflicts.

Going further, the consideration of bravely is in part inherited from the chivalric mental developments in European later medieval society where chivalry and knighthood grew up. If we consider the ideal of gentleman and soldier, especially in the Southern states, the chivalric ideals of the European medieval chivalry were not so far away from American antebellum and war mentality. There is in the twelfth and thirteenth centuries when, as Robert Fossier remarks, the new culture of the aristocracy grows up in European society around the warrior values, so much appreciated by the knights (Fossier, 1988, p. 369). Following Georges Duby, there are four main values of the medieval chivalry of the thirteenth century: honour, courtesy, honesty and prowess. ${ }^{16}$ We can add another, the largesce [generosity], pointed by Erich Köhler, the social generosity with peers and with those with lower status (Köhler, 1990, p. 32). Crossing time through Amer- 
ican Between the States War, Robert E. Lee explains his sense of chivalry and the chivalric ideal from South perspective in one paper edited by Emory M. Thomas and remarked by Gale Sigal. He points here the main virtues of the southern gentleman and chivalry, virtues that are not so far from European medieval knight (Sigal, 2016, p. 169). These are for sure power and strength, education and refinement but also mercy and the avoiding using that power and strength:

The power which the strong have over the weak, the magistrate over the citizen, the employer over the employed, the educated over the unlettered, the experienced over the confiding, even the clever over the silly-the forbearing or inoffensive use of all this power or authority, or a total absence from it when the case admits it, will show the gentleman in plain light (Sigal, 2016, p. 169).

This is not an unconscious or casual association. The presence of these has its stronger point in medieval literature, especially in Arthurian cycle, and the diffusion of this genre in nineteenth century American literary circles explains the assumption of some of those mental schemes from centuries ago. The work of Sir Thomas Malory, named the Mort d'Arthur, is one of those medieval texts re-edited and diffused along this time in America and that had impact with editions as The Age of Chivalry, or Legends of King Arthur by Thomas Bulfinch in 1858, or legend of Charlemagne in 1862. Works of Walter Scott and Mark Twain, receiving the medieval stories, tales and conceptions and rethinking them for a new literature, played also their game.

The reception of these traditions was changing progressively, from funny and satirical considerations in the beginning of the century to a most serious perception going forward through the ante bellum period and approaching the War. Novelists and southern literati, especially in the post bellum times, associated the Arthurian myth and medieval legendary spirit with the glorification of the defeated Confederation and its fallen leaders and soldiers through chivalry and knighthood (Taylor and Brewer, 1983, p. 163). ${ }^{17}$

In a more concrete way, the mere title Mohun: Or, The Last Days of Lee and His Paladins, published by John Esten Cooke at 1869, receives and follows this medieval Arthurian tradition, giving the epic sense of chivalric literature to the fall of the Confederate States. The void opened in the Confederacy with the deaths of the general Thomas Jonathan 'Stonewell' Jackson at Chancelloursville, in 1863, and of James Ewell Brown 'Jeb' Stuart, at Yellow Tavern, in 1864, is treated here as the fall of brave knights and heroes with the same epic and tragic sense than King Arthur's knights of the Round Table. The model of the classic medieval literary tradition is clear:

Where should I turn now-and wither should I go? Jackson dead at Chancelloursville-Stuart at Yellow Tavernthenceforth I seemed to have lost my support, to grope and totter in darkness, without a guide! These two kings of battle had gone down in the storm, and, like the Knight of Arthur, I looked around me, with vacant and inquiring eyes, asking wither I was now to direct my steps (Cooke, 1968, p. 157)

The treatment given to these southern military, especially Jeb Stuart, takes the external form of the vision of the medieval knight, mixing medieval literature and conceptions with the most recent tradition and writing taste of the Romanticism:

It is in June, 1863, therefore, worthy reader, that I open my volume. Up to that time I had gone with Jackson's 'foot cavalry,' marching slowly and steadily to battle. Now, I was to follow the gay and adventurous career of the Virginia Rupert - Stuart, the Knight of the Black Plume! [...]

In that ride through the May forest, to attack Sheridan, and arrest him or die, Stuart's bearing and expression were superbly joyous and inspiring. His black plume floated in the spring breeze, like some knight-errant's; and he went to battle humming a song, resolved to conquer or fall (Cooke, 1968, pp. 10 and 204).

This comparison goes further and clearer in the figure of Robert Lee and the image that Thomas Nelson Page gives on his biography of the general Robert E. Lee. Man and Soldier, published in 1911, with the vision of a Round Table knight and the Middle Ages military estate; a modern and contemporary reception and adaptation of the bellatores [those who fight]:

On one of these occasions, he was approached with a tender of the presidency of an insurance company at a salary of $\$ 50,000$ a year. He declined it on the ground that it was work with which he was not familiar. 'But, general,' said the gentleman who represented the insurance company, 'you will not be expected to do any work; what we wish is the use of your name.' 'Do you not think' said General Lee, 'that if my name is worth $\$ 50,000$ a year, I ought to be very careful about taking care of it?"

Amid the commercialism of the present age this sounds as refreshing as the oath of a knight of the Round Table.

Defeated in one warfare, he was still a captain militant in the service of Duty: Duty that, like the moon, often shows her darkened face to her votary, though in the future she may beam with radiance (Page, 1911, pp. 647-648).

This is even more explicit with the reference of those medieval chivalric values now attributed to General Lee:

He remained as unmoved as he had stood when he had held the heights of Fredericksburg against the furious attacks of Burnside's intrepid infantry. From, this inquisition he came forth as unsoiled as the mystic White Knight of the Round Table. In that vivid glare he stood revealed in the full measure of nobility - the closest scrutiny but brought forth new virtues and disclosed a more rounded character: "Like Launcelot brave, like Galahad clean" (Page, 1911, pp. 686)

Like Lancelot brave. Like Galahad, clean. This is not only literature nor a medieval chivalric cycle: this 
is the reception of a set of medieval values of the military aristocracy from the centre and Late Middle Ages that arrived to the American ante bellum, war times and post bellum periods, even changed now and adapted. Values receipted and assumed as valid in some cases for the formation of new generations. That is how we have Twentieth Century Knighthood: A Series of Addresses to Young Men, by Louis Albert Bank in 1900, a work that receives the concept and idea of chivalry and knighthood and explains them through some contemporary examples as presidents Abraham Lincoln or Ulysses S. Grant ${ }^{18}$.

The concept of Southern chivalry was assumed in the North as an anachronism and during the War Between the States some media, especially The New York Times, published some editorials and articles with barely humoristic critics about $\mathrm{it}^{19}$. The editorials pointed on this particular mentality space, in the falsehood of reality with respect to those theoretical behaviours and also on the European circles where this chivalric reminds where applauded, namely on the editorial $A$ Word to the Europeans Admirers of Southern Chivalry, on April 129, 1864.

$$
* * *
$$

Centuries and continents separated by time and distance but linked by sets of theoretical formulations on political and cultural spaces. This paper has avoided the coincidences and focused on continuities. The European medieval world was rich on theoretical reflections with the development on middle and Late Middle Ages of the new political systems that were to change the world geopolitically.

Arthurian literature, federalism and constitutionalism, concepts of war... we linked here some concepts formulated on Europe during medieval times; concepts that not disappeared with the evolution of times to Modern age but evolved on new forms. In this paper, we found vestiges of these theorizations, remnants of these ideas in places where maybe we less expect, the most remarkable American periods on its intern history: the Independence years and the Between the States war times. Changed, of course; rethought, for sure. However, present and clear as the voice of the texts; because its main characters were, most of the times, conscious of that influences and of the presence of that principles.

\section{ACKNOWLEDGEMENTS}

The author is grateful to George D. Greenia, professor emeritus of the College of William and Mary (Williamsburg, VA). This article owes him part of its form, through our conversations and always enthusiastic and generous

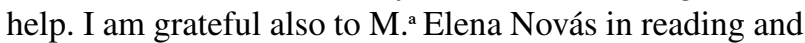
her always accurate commentary.

\section{NOTES}

1 There are many studies in the different national traditions that deepen this field. See: Evans, Fulton and Matthews, 2006; Noorur, 2018. The work of Shah Noorur points especially to the long persistence, considering culture and religion in a "medieval period" that extends from 1204 to 1757 (Noorur, 2018, p. 53).

2 As Lieberman, 2003; or the recent Journal of Transcultural Medieval Studies, published since 2014; see: Tischler, 2018.

3 In the discourse about war and cultural studies, see: Brown and Górecki, 2003.

4 In recent times see the series Studies in Medieval and Early Modern Culture and Research in Medieval and Early Modern Culture with themes defined from the annual International Congress on Medieval Studies at Kalamazoo.

5 On History as justifier of political actions see: Anderson, 1967; Levi, 2010.

6 In order to a historiographical prespective: Hammersley, 2012. An extensive approach: Gelderen and Skinner, 2002.

7 As interpretative tools, we have to link this theoretical approach to the "political languages" system of Pocock. As recent collection of ideas and works, see: Pocock, 2009.

8 "El Senado recoge los intereses de los partidarios de mantener la separación de las antiguas colonias británicas entre sí y la Cámara de Representantes los de quienes aspiran a un solo estado unitario" (Hijano, 1997, p. 74).

9 For a recent general approach to medieval European sovereignty see: Sturges, 2011.

10 For the evolution of this concept, see: Rosales, 1988, pp. 121134

11 On implications of the religious legitimation in Culture and in political systems: Bisin, Seror and Verdier, 2019.

12 "European Enlightenment thought had certainly crossed the Atlantic, but it did not seriously weaken the influence of the Churches or of the Christian tradition" (Dowling, 2009, p. 43).

13 Beyond, Mathews develops a very interesting analysis on the persistence of the figure of Dante until present times on North American popular culture.

14 "For many unionists, this narrative arc was especially potent for its (supposed) promotion of the moral necessity of national unity and western imperialism, and for its condemnation of political traitors and rebels" (Matthews, 2013, p. 317).

15 On Between the States war: "all combat and postcombat behaviour took place in an environment of value and expectation about individual performance far closer to that of the Greeks and medieval conceptions than to those of our time. Soldiers were either brave or cowardly" (Marlowe, 2011, p. 18). This points on the difficulty of comparison of terms (Herzfeld, 1980, p. 339340). Applying concepts in medieval war see: Hodgson, 2013. And in related and close subjects: Flannery, 2012.

16 Among other works, this mainly developed in: Duby, 1984. On some of those values and the historical sense from literature, recently: Bremmer, 2014.

17 Some authors followed this path explaining the chivalric southern sense through medieval literary cycles, named the Arthurian and the works of Thomas Malory. Authors as Sidney Lanier with The Boy's King Arthur, who, re-reading and re-thinking Malory, gives us one mixture of chivalry, medieval values and nineteenth-century society.

18 On this subject Barbara Tepa Lupack developed some time ago a whole essay around this reception and renovation (Lupack, 2004).

19 Gale Sigal names the editorial of Nov. 8, 1853 (Sigal, 2016, p. 169). 


\section{REFERENCES}

Amer, S. and Ramey, L. (2018) "Teaching the Global Middle Ages through Technology". Parergon, 35/2, pp. 175-187. doi: https:// doi.org/10.1353/pgn.2018.0071

Anderson, O. (1967) "The political uses of history in mid nineteenth-century England". Past \& Present, 36/, pp. 87-105. doi: https://doi.org/10.1093/past/36.1.87

Aurell Cardona, J., ed. (2005-2009-2015) Rewriting the Middle Ages in the Twentieth Century, 3 vols. Turnhout: Brepols Publishers.

Belkot, A., Kandulski, S. and Kosinska, M. (2014) Cultural theory and history: The change and everyday life. Poznan: Wydawnictwo Naukowe Wydziału Nauk Społecznych.

Berman, J. (2019) "The Biblical Criticism of Ibn Hazm the Andalusian: A Medieval Control for Modern Diachronic Method". Journal of Biblical Literature, 138/2, pp. 377-390. doi: https:// doi.org/10.15699/jbl.1382.2019.511588

Bisin, A., Seror, A. and Verdier, Th. (2019) "Religious Legitimacy and the Joint Evolution of Culture and Institutions". In: J. P. Carvalho, S. Iyer and J. Rubin, eds., Advances in the Economics of Religion. International Economic Association Series. [Cham]: Palgrave Macmillan, pp. 321-332.

Black, A. (1992) Political Thought in Europe, 1250-1450. Cambridge: Cambridge University Press.

Black, J. (2009) Absolutism in Renaissance Milan. Plenitude of Power Under the Visconti and the Sforza 1329-1535. Nueva York: Oxford University Press.

Blockmans, W. (2008) "The Medieval Origins of Constitutional Representation". In: Europaeum lectures. Oxford: Europaeum.

Boisi Center for Religion and American Public Life (2007) "Separation of Church and State". In: Boisi Center Papers on Religion in the United States. https://www.bc.edu/content/dam/files/centers/boisi/ pdf/bc_papers/BCP-ChurchState.pdf [Accessed 4 February 2020]

Borden, M., ed. (1965) The Antifederalist Papers. Michigan: Michigan State University Press.

Bremmer, R. (2014) "Shame and Honour in Anglo-Saxon Hagiography, with Special Reference to Aelfric's Lives of Saints." In: L. Lazzari, P. Lendinara and C. Di Sciacca (2014) Hagiography in Anglo-Saxon England: Adopting and Adapting Saints'Lives into Old-English Prose (c. 950-1150). Turnhout: Brepols Publishers, pp. 95-119. doi: https://doi.org/10.1484/M.TEMA-EB.4.01015

Brice, S. (2015) "A Classy Constitution: Classical Influences on the United States Constitution from Ancient Greek and Roman History and Political Thought". Senior Honor projects, 85. https:// collected.jcu.edu/honorspapers/85 [Accessed 4 February 2020]

Brown, W. C. and Górecki, P., eds. (2003) Conflict in Medieval Europe: Changing Perspectives on Society and Culture. Aldershot: Routledge.

Buratti, A. (2016) Western Constitutionalism. An introduction. Milano: G. Giappichelli Editore.

Carey, G. W. and McClellan, J., eds. The federalist. Indianapolis: Liberty Fund, Inc.

Cheney, J. V. (1910) Memorable American Speeches, IV. Secession, War, Reconstruction. Chicago: The Lakeside Press.

Collings, J. (2017) "What Should Comparative Constitutional History Compare?". University of Illinois Law Review, paper 1708. doi: https://doi.org/10.2139/ssrn.2919041

Condorelli, O. (2014) "Quod omnes tangit, debet ab omnibus approbari”. In: J. Øyrehagen Sunde, ed., Constitutionalism before 1789 constitutional arrangements from the high Middle Ages to the French revolution. Oslo: Pax Forlag, pp. 60-74.

Cooke, J. E. (1968) Mohun: Or, The Last Days of Lee and His Paladins. Final memoirs of a staff office serving in Virginia. Ridgewood: The Gregg Press Incorporated.

Dowling, M. (2009) "The American Churches and the Civil War". Perichoresis, 7/1, pp. 39-69.

Duby, G. (1984) Guillaume le Maréchal ou le meilleur chevalier du monde. Paris: Fayard.

Enlow, E. (2001) "The Corporate Conception of the State and the Origins of Limited Constitutional Government". Washington
University Journal of Law \& Policy, 6. https://openscholarship. wustl.edu/law_journal_law_policy/vol6/iss $1 / 2$ [Accessed 4 February 2020]

Esbeck, C. H. (2004) "Dissent and Disestablishment: The ChurchState Settlement in the Early American Republic". BYU Law Review, 4, pp. 1385-1592.

Español, D. (2019) "New perspectives for the dissemination of medieval history: re-enactment in southern Europe, a view from the perspective of didactics". Imago Temporis. Medium Aevum, XIII, pp. 333-359. doi: https://doi.org/10.21001/ itma.2019.13.15

Evans, R., Fulton, H. and Matthews, D., eds. (2006) Medieval Cultural Studies: Essays in Honour of Stephen Knight. Cardiff: University of Wales Press, 2006.

Evans, R. and Marchal, G. P., eds. (2011). The Uses of the Middle Ages in Modern European States. History, Nationhood and the Search for Origins. Houndmills, Basingstoke: Palgrave Macmillan.

Flannery, M. C. (2012) "The Concept of Shame in Late-Medieval English Literature", Literature Compass, 9/2, pp. 166-82. doi: https://doi.org/10.1111/j.1741-4113.2011.00868.x

Fossier, R. (1988) La Edad Media (v. 2). Barcelona: Editorial Crítica.

Frankopan, P. (2019) "Why We Need to Think About the Global Middle Ages". Journal of Medieval Worlds, 1/1, pp. 5-10. doi: https://doi.org/10.1525/jmw.2019.100002

Freedman, P. and Spiegel, G. M. (1998) "Medievalisms Old and New: The Rediscovery of Alterity in North American Medieval Studies". The American Historical Review, 103/3, pp. 677-704. doi: https://doi.org/10.2307/2650568

Gelderen, M. and Skinner, Q. eds. (2002) Republicanism: A Shared European Heritage. 2 vols. Cambridge: Cambridge University Press.

Girgensohn, D. (2007), „Von der konziliaren Theorie des späteren Mittelalters zur Praxis: Pisa 1409”. In: H. Müller and J. Helmrath, eds., Die Konzilien von Pisa (1409), Konstanz (1414-1418) und Basel (1431-144). Institutionen und Personen. Stuttgart: Jan Thorbecke, pp. 61-94.

Godthardt, F. (2014) "Marsilius von Padua als politische Herausforderung für Johannes XXII". In: H.-J. Schmidt and M. Rohde, eds., Papst Johannes XXII. Konzepte und Verfahren seines Pontifikats. Berlin: De Gruyter, pp. 75-118.

González Díez, E., dir. (2018) Las Cortes de León: cuna del parlamentarismo. Madrid: Centro de Estudios Políticos y Constitucionales.

Grewal, D. S. and Purdy, J. (2018) "The original theory of constitutionalism. The sleeping sovereign: The invention of Modern Democracy". The Yale Law Journal, 127/3, pp. 664-705.

Hammersley, R. (2012). "Introduction: The Historiography of Republicanism and Republican Exchanges". History of European Ideas, 38/3, pp. 323-337. doi: https://doi.org/10.1080/0191659 9.2012.674837

Helmholz, R. H. (2016) "The myth of Magna Carta revisited". North carolina Law Review, 94/5, pp. 1475-1494.

Herlihy, D., ed. (1968) Medieval culture and society. London: Palgrave Macmillan.

Herzfeld, M. (1980) "Honour and Shame: Problems in the Comparative Analysis of Moral Systems", Man, 15/2, pp. 339-351. doi: https://doi.org/10.2307/2801675

Hijano Pérez, A. (1997) "La Guerra de Secesión estadounidense: ¿la solución de un problema político?". REDEN: Revista española de estudios norteamericanos, 13, pp. [63]-79.

Hodgson, N. R. (2013) "Honour, shame and the Fourth Crusade". Journal of Medieval History, 39/2, pp. 220-239. doi: https://doi. org/10.1080/03044181.2013.779297

Holmes, C. and Standen, N. (2015) "Defining the Global Middle Ages". Medieval worlds, 1, pp. 106-117. doi: https://doi. org/10.1553/medievalworlds_no1_2015s106

Holmes, C. and Standen, N. (2018) "Introduction: Towards a Global Middle Ages". Past and Present, 238/13, November, pp. xiixxi. doi: https://doi.org/10.1093/pastj/gty030 
Kaeuper, R., ed. (2013) Law, Governance, and Justice. New Views on Medieval Constitutionalism. Leiden: Brill.

Köhler, E. (1990) La aventura caballeresca. Ideal y realidad en la narrativa cortés. Barcelona: Ed. Sirmio.

Kuon, P. (1996) "Die kreative Rezeption der Divina Commedia in Klassik und Romantik". In: F.-R. Hausmann, M. Knoche and H. Stammerjohann, "Italien in Germanien". Deutsche ItalienRezeption von 1750-1850. Tübingen: Narr Francke Attempto, pp. 300-317.

LaCroix, A. (2008) "Drawing and Redrawing the Line: The PreRevolutionary Origins of Federal Ideas of Sovereignty". University of Chicago Law Occasional Paper, 47. https://chicagounbound. uchicago.edu/cgi/viewcontent.cgi?referer=https://www.google. com/\&httpsredir $=1 \&$ article $=1009 \&$ context=occasional_papers [Accessed 07 February 2020]

Lampart F. (2010) "Dante's reception in German literature: a question of performance?". In: M. Gragnolati and A. Suerbaum, Aspects of the Performative in Medieval Culture. Berlin/New York: Walter de Gruyter GmbH \& Co. KG, pp. 277-298.

Landi, Aldo (1985), Il Papa deposto (Pisa 1409): l'idea conciliare nel Grande Scisma. Torino: Claudiana.

Levi, G. (2010) "The Distant Past: On the Political Use of History". Mediterranean Historical Review, 16/1, pp. 61-73. doi: https:// doi.org/10.1080/714004564

Lieberman, V. (2003) Strange Parallels: Southeast Asia in Global Context, c. 800-1830, 2 vols. Cambridge: Cambridge University Press.

López Alcaide, C., Puig Montada, J. and Roche Arnas, P., eds. (2018) Legitimation of Political Power in Medieval Thought. Acts of the XIX Annual Colloquium of the Société Internationale pour l'Étude de la Philosophie Médiévale Alcalá, 18-20 September 2013. Turnhout: Brepols.

Lukes, D. (2014) "Comparative neomedievalisms: A little bit medieval". Postmedieval: a journal of medieval cultural studies volume, 5, pp. 1-9. doi: https://doi.org/10.1057/ pmed.2013.41

Lupack, B. T. (2004) Adapting the Arthurian Legends for Children: Essays on Arthurian Juvenilia. New York: Palgrave McMillan.

Meriwether, J. L. and D'Amore, L. M. (2012) We Are What We Remember: The American Past Through Commemoration. Newcastle: Cambridge Scholars Publishing.

Marlowe, D. H. (2011) Psychological and Psychosocial Consequences of Combat and Deployment with Special Emphasis on the Gulf War. Santa Monica, CA: RAND Corporation.

Matthews, D. (2015) Medievalism: A Critical History. Boydell \& Brewer.

Matthews, J. (2013) "Divine Comedy as an American Civil War Epic". J19: The Journal of Nineteenth-Century Americanists, 1.2, pp. 315-337. doi: https://doi.org/10.1353/jnc.2013.0032

Matthews, J. S. (2012) The American Alighieri: receptions of Dante in the United States, 1818-1867. An abstract. Iowa City, IA: University of Iowa.

McMullan, G. A. and Matthews, D. eds. (2007) Reading the Medieval in Early Modern England. Cambridge: Cambridge University Press.

Møller, J. (2015) “The Medieval Roots of Democracy”. Journal of Democracy, 26/3, pp. 110-123. doi: https://doi.org/10.1353/ jod.2015.0042

Montani, D. (2014-2015) The right to secede: a comparative analysis. Tesi di laurea in Comparative public law. https://pdfs.semanticscholar.org/20ca/645b2813c247806d44d2403eeb9c6cc99edb.pdf [Accessed 4 February 2020]
Nelson-Campbell, D. H. and Cholakian, R. Ch., eds. (2017) The legacy of courtly literature: from medieval to contemporary culture. Cham: Palgrave Mcmillan.

Noorur Rahman, S. (2018) "Religious and Cultural Syncretism in Medieval Bengal". The NEHU Journal, XVI/1, pp. 53-77.

Oakley, F. (2003) The Conciliarist Tradition: Constitutionalism in the Catholic Church, Oxford: Oxford University Press.

Page, T. N. (1911) Robert E. Lee. Man and Soldier. New York, NY: Charles Scribner's Sons.

Pocock, J. G. A. (2009) Political Thought and History: Essays on Theory and Method. Cambridge: Cambridge University Press.

Rosales, J. M. (1988) "La crisis del paradigma político medieval. Una reflexión sobre el debate de la teología política”. Revista Española de Filosofía Medieval, 5, pp. 121-134. doi: https://doi. org/10.21071/refime.v5i.9686

Ruiz Ruiz, R. (2013) "Republicanismo clásico en el pensamiento hispano: una tradición frustrada". Anales de la Cátedra Francisco Suárez, 47, pp. 273-297.

Ryan, L. (2017) "James Martin Cawdell and Medieval Politics in Early Canada". Studies in Canadian Literature / Études En littérature Canadienne, 42/1. https://journals.lib.unb.ca/index. php/SCL/article/view/25939/30140 [Accessed 06 February 2020]

Satrústegui Gil-Delgado, M. (2009) "La Magna Carta: realidad y mito del Constitucionalismo pactista medieval". Historia Constitucional, 10, pp. 243-262. doi: https://doi.org/10.17811/ hc.v0i10.232.g205

Sautkin, A. (2015) "Historical reenactment as stylized identity and its creative potential: Bakhtinian approach to The socio-cultural identity". Creativity studies, 8(1), pp. 25-41. doi: https://doi.org $/ 10.3846 / 23450479.2014 .979892$

Seibert, H., ed. (2014) Ludwig der Bayer (1314-1347). Reich und Herrschaft im Wandel, Regensburg: Schnell \& Steiner.

Sigal, G. (2016) "At What Price Arthur? Academic Autobiography Medieval Studies and the American Medieval". In: G. R. Overing and U. Wiethaus, eds., American/Medieval. Nature and Mind in Cultural Transfer. Gottingen: V\&R Unipress, pp. 151-174.

Simpson, J. (2007), "Diachronic history and the shortcommings of medieval studies". In: G. A. McMullan and D. Matthews, eds., Reading the Medieval in Early Modern England. Cambridge: Cambridge University Press.

Stout, H. S. (2006) Upon the Altar of the Nation: A Moral History of the Civil War. New York: Penguin Books.

Sturges, R. S. (2011) Law and Sovereignty in the Middle Ages and the Renaissance. Turnhout: Brepols Publishers

Tavares Magalhães, A. P. (2008) "O papado avinhonense e os poderes civis: as décadas de 30 e de 40 do século XIV a partir de três obras de Guilherme de Ockham". História, 27/2, pp. 223-251.

Taylor, B. and Brewer, E. (1983) The return of king Arthur. British and American Arthurian literature since 1800. Cambridge: Barnes and Noble books.

Tischler, M. M. (2018) "Medieval Mental Maps", Journal of Transcultural Medieval Studies, 5/2, pp. 211-213. doi: https://doi. org/10.1515/jtms-2018-0018

Washington, G. (19 September 1796) Our Documents. https://www. ourdocuments.gov/doc.php?flash=false $\&$ doc $=15 \&$ page $=$ transcript [Accessed 04 February 2020]

Yarrow, S. (2018), "Economic imaginaries of the global Middle ages", Past and Present, 238/13, November, pp. 214-231. doi: https://doi.org/10.1093/pastj/gty029

Zenari, V. (2015) "Henry James's Civil War Stories. The Homefront Experience and War Romance". War, Literature and the Arts, 27 , pp. $1-40$. 